\title{
Ethanolic Fermentation of 'Bartlett' Pears as Influenced by Ripening Stage and Atmospheric Composition
}

\author{
Dangyang Ke, Elhadi Yahia', Mila Mateos, and Adel A. Kader ${ }^{2}$ \\ Department of Pomology, University of California, Davis, CA 95616
}

Additional index words. Pyrus communis, pyruvate decarboxylase, alcohol dehydrogenase, anaerobic volatiles, cytoplasmic $\mathrm{pH}, \mathrm{NADH}$

\begin{abstract}
Changes in fermentation volatiles and enzymes were studied in preclimacteric and postclimacteric 'Bartlett' pears (Pyrus communis L.) kept in air, $0.25 \% \mathrm{O}_{2}, 20 \% \mathrm{O}_{2}+80 \% \mathrm{CO}_{2}$, or $0.25 \% \mathrm{O}_{2}+80 \% \mathrm{CO}_{2}$ at $20 \mathrm{C}$ for 1,2 , or 3 days. All three atmospheres resulted in accumulation of acetaldehyde, ethanol, and ethyl acetate. The postclimacteric pears had higher activity of pyruvate decarboxylase (PDC) and higher concentrations of fermentation volatiles than those of the preclimacteric fruit. For the preclimacteric pears, the $0.25 \% \mathrm{O}_{2}$ treatment dramatically increased alcohol dehydrogenase (ADH) activity, which was largely due to the enhancement of one $\mathrm{ADH}$ isozyme. Exposure to $20 \% \mathrm{O}+80 \% \mathrm{CO}$ slightly increased ADH activity, but the combination of $0.25 \% \mathrm{O}_{2}+80 \% \mathrm{CO}_{2}$ resulted in lower $\mathrm{ADH}$ activity than $0.25 \% \mathrm{O}_{2}$ alone. For the postclimacteric pears, the three atmospheres resulted in higher PDC and ADH activities than those of air control fruit. Ethanolic fermentation in 'Bartlett' pears could be induced by low $\mathrm{O}_{2}$ and/or high $\mathrm{CO}_{2}$ via 1 ) increased amounts of $\mathrm{PDC}$ and ADH; 2) PDC and ADH activation caused by decreased cytoplasmic pH; or 3) PDC and ADH activation or more rapid fermentation due to increased concentrations of their substrates (pyruvate, acetaldehyde, or NADH).
\end{abstract}

Exposing harvested fruit to low $\mathrm{O}_{2}$ and/or high $\mathrm{CO}_{2}$ can be beneficial or harmful, depending on concentrations of these gases, temperature, exposure duration, and commodity. Beneficial effects include disease control, insect disinfestation, and alleviation of chilling injury and other physiological disorders. We have investigated the tolerance limits of several fruit, including pears, to such fungicidal and insecticidal atmospheres and the capacity of the fruit tissue to recover from exposure to low $\mathrm{O}_{2}$ and/or high $\mathrm{CO}_{2}$ for short durations.

Ethanolic fermentation is a major pathway induced in plant tissues in response to very low $\mathrm{O}_{2}$ and/or very high $\mathrm{CO}_{2}$ concentrations. In this pathway, acetaldehyde is produced through pyruvate decarboxylation catalyzed by PDC. The enzyme ADH reduces acetaldehyde into ethanol using NADH. Ethanol is usually the major product of the pathway in low $\mathrm{O}_{2}$-stressed fruit ( $\mathrm{Ke}$ and Kader, 1992; Ke et al., 1991b), but in some fruit tissues, part of the ethanol is converted into ethyl acetate. In $\mathrm{CO}_{2}$-zymasis, the ratio of ethanol to acetaldehyde was 2:1, contrasting strikingly with 50:1 obtained in anaerobic zymasis in apple (Thomas, 1929).

Oxygen levels $<1 \%$ or $\mathrm{CO}_{2}$ levels $>20 \%$ caused acetaldehyde and ethanol accumulation in apples (Ke et al., 1991b; Knee, 1991; Nichols and Patterson, 1987; Thomas, 1929), pears (Ke et al., 1990, 1991b), stone fruit (Ke and Kader, 1992; Smilanick and Fouse, 1989), oranges (Ke and Kader, 1990), strawberries (Keetal., 1991a), blueberries (Saltveit and Ballinger, 1983a), grapes (Saltveit and Ballinger, 1983b), carrots (Leshuk and Saltveit, 1991), and sweetpotatoes (Chang et al., 1982, 1983). Increased PDC and ADH activities were found in sweetpotatoes (Chang et al., 1982, 1983), tomatoes (Longhurst et al., 1990), avocadoes (Kanellis et al., 1991), and pears (Nanos et al., 1992) in response to low $\mathrm{O}_{2}$ or high $\mathrm{CO}_{2}$.

Received for publication 15 Oct. 1993. Accepted for publication 17 Mar. 1994. Research supported in part by U.S. Dept. of Agriculture research agreement no. 58319R-3-004. The work of M. Mateos was supported by a grant from the Dirección General de Investigación Cientifica y Tecnica (Ministerio de Educación Ciencia), Spain. The cost of publishing this paper was defrayed in part by the payment of page charges. Under postal regulations, this paper therefore must be hereby marked advertisement solely to indicate this fact.

${ }^{1}$ Current address: CIAD, Apartado Postal 1735, Hermosillo, Sonora 83000, Mexico. ${ }^{2}$ To whom reprint requests should be addressed.
Although intensive research has been done on anaerobic metabolism in maize, barley, and rice (Davies, 1980; Gerlach et al., 1982; Good and Crosby, 1989; John and Greenway, 1976; Kelley, 1989; Kennedy et al., 1992; Roberts, 1989; Roberts et al., 1989), the mechanism for regulation of ethanolic fermentation in fruit is not clear. In this research, we studied the regulating ethanolic fermentation in 'Bartlett' pears kept in $0.25 \% \mathrm{O}_{2}, 20 \% \mathrm{O}_{2}+80 \%$ $\mathrm{CO}_{2}$, or $0.25 \% \mathrm{O}_{2}+80 \% \mathrm{CO}_{2}$ as influenced by ripening stage.

\section{Materials and Methods}

Materials and treatments. 'Bartlett' pears were obtained on the day of harvest (at the mature-green stage of maturity) from commercial shippers in Lake County, Calif., and stored in air at 0C until used for experiments. Ripening stage was estimated by measuring skin color using a color difference meter (CDM) calibrated with a white plate $(\mathrm{x}=84.1, \mathrm{y}=81.7, \mathrm{z}=92.9)$ and respiration and ethylene production rates. Preclimacteric pears were stored in air at $0 \mathrm{C}$ for $<2$ weeks before being used for experiments; their skin color was green with an average CDM "a" value of -18.3 . To obtain postclimacteric pears, the fruit were stored in air at $0 \mathrm{C}$ for $>2$ weeks and then, if necessary, held in air at $20 \mathrm{C}$ for a certain period to allow them to ripen. During this holding period, respiration and ethylene production rates were monitored and, immediately after the pears passed the climacteric peak, they were used for experiments. The postclimacteric pears had green-yellow skin color with an average CDM "a" value of 8.6. For each experiment, fruit were selected for freedom from defects and matched by color. Nine fruit were placed in a 4-liter glass jar and ventilated with humidified air or a desired gas mixture at a continuous $100-\mathrm{ml} \cdot \mathrm{min}^{-1}$ flow rate. The gas mixtures included $0.25 \% \mathrm{O}_{2}\left(+99.75 \% \mathrm{~N}_{2}\right), 20 \% \mathrm{O}_{2}+80 \% \mathrm{CO}_{2}$, and $0.25 \% \mathrm{O}_{2}+80 \%$ $\mathrm{CO}_{2}\left(+19.75 \% \mathrm{~N}_{2}\right)$. Three replicates were used for each treatment. The fruit samples were kept in air or the specified atmospheres at $20 \mathrm{C}$ for 1,2 , or 3 days. The preclimacteric pears were subsequently transferred to air at $20 \mathrm{C}$ for another 3 days to observe the postcontrolled atmosphere (CA)-stress changes.

Volatile measurement. Frozen pear juice was thawed and a 5$\mathrm{ml}$ sample was put in a 10-ml screw-cap test tube, which was closed 
with a plastic cap and incubated in a water bath at 60C. After 60 min, a headspace sample was taken with a 1-ml glass syringe for determining acetaldehyde, ethanol, and ethyl acetate concentrations using a gas chromatograph (HP5890A; Hewlett Packard, Palo Alto, Calif.) with a flame ionization detector (at 250C) and a glass column $(2 \mathrm{~mm} \times 1.0 \mathrm{~m})$ containing $5 \%$ Carbowax on $60 / 80$ Carbopack as stationary phase (Supelco, Bellafonte, Pa.) at 85C.

Enzyme extraction and assay. For each replicate, $3 \mathrm{~g}$ tissue was obtained from three fruit and homogenized in $10 \mathrm{ml}$ of $100 \mathrm{~mm} 2-$ ( $N$-morpholino)ethane-sulfonic acid (MES) buffer ( $\mathrm{pH} 6.5$ ) containing $2 \mathrm{~mm}$ dithiothreitol and $1 \%(\mathrm{w} / \mathrm{v})$ polyvinylpyrolidone (PVP). The homogenate was filtered through four layers of cheesecloth and centrifuged at $27,000 \times g$ for $10 \mathrm{~min}$. The supernatant was retained as enzyme extract for measuring PDC and ADH activities. PDC was assayed through coupling with ADH reaction by mixing $0.45 \mathrm{ml}$ of $100 \mathrm{~mm}$ MES buffer ( $\mathrm{pH} 6.5), 0.1 \mathrm{ml}$ of $5 \mathrm{~mm}$ thiamine pyrophosphate, $0.1 \mathrm{ml}$ of $50 \mathrm{~mm} \mathrm{MgCl}_{2}, 0.05 \mathrm{ml}$ of $1.6 \mathrm{~mm} \mathrm{NADH}$, $0.1 \mathrm{ml}$ of commercial ADH solution (containing 13.5 enzyme units), $0.1 \mathrm{ml}$ of enzyme extract, and $0.1 \mathrm{ml}$ of $50 \mathrm{~mm}$ pyruvate. ADH activity was measured by mixing $0.8 \mathrm{ml}$ of $100 \mathrm{~mm}$ MES buffer ( $\mathrm{pH} 6.5$ ), 0.05 $\mathrm{ml}$ of $1.6 \mathrm{~mm} \mathrm{NADH}, 0.1 \mathrm{ml}$ of enzyme extract, and $0.05 \mathrm{ml}$ of 80 mM acetaldehyde. For PDC and ADH, NADH oxidation was measured by recording the decrease in absorbance at $340 \mathrm{~nm}$ using a spectrophotometer. Enzyme activities were expressed as moles of substrate used per minute per gram of fresh weight. For in vitro studies of enzyme kinetics, several assay $\mathrm{pH}$ values and substrate

\section{Preclimacteric pear}

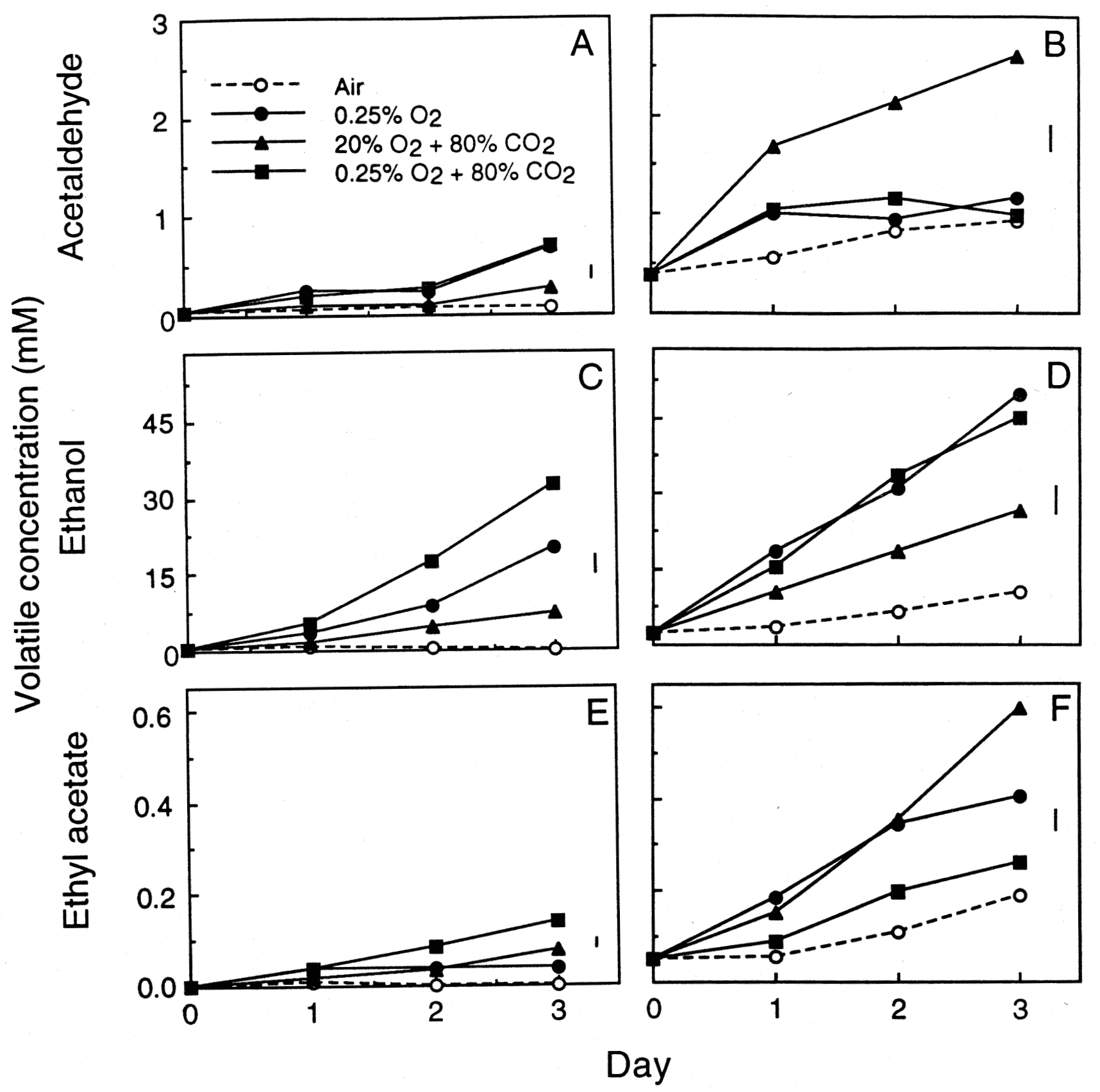

\section{Postclimacteric pear}

Day

Fig. 1. Changes in acetaldehyde, ethanol, and ethyl acetate concentrations in preclimacteric and postclimacteric 'Bartlett' pears kept in air, $0.25 \% \mathrm{O}_{2}, 20 \% \mathrm{O}_{2}+80 \% \mathrm{CO}_{2}$, or $0.25 \% \mathrm{O}_{2}+80 \% \mathrm{CO}_{2}$ at $20 \mathrm{C}$ for 1,2 , or 3 days. The vertical bars represent LSD at $P=0.05$. 
concentrations of pyruvate, acetaldehyde, and NADH were used to study the changes in PDC and ADH activities.

ADH isozyme extraction, electrophoresis, and staining. Nine grams of fruit tissue was homogenized in $12 \mathrm{ml}$ extraction buffer and $1 \mathrm{~g}$ polyvinyl-polypyrrolidone (PVPP). The homogenate was filtered through four layers of cheesecloth and centrifuged at 27,000× $g$ for $10 \mathrm{~min}$. The supernatant was retained for isozyme analysis by starch gel electrophoresis. The gels were prepared and run, and ADH isozymes were stained according to Arulsekar and Parfitt (1986).

\section{Results and Discussion}

Changes in fermentation volatiles and enzymes. For the postclimacteric 'Bartlett' pears, acetaldehyde, ethanol, and ethyl acetate concentrations increased when the fruit were kept in air at 20C for 2 to 3 days (Fig. 1). For the preclimacteric pears, such increases in volatiles of the air control fruit occurred only after 6 days when the fruit were ripe (Table 1). Acetaldehyde, ethanol, and ethyl acetate production seems to be a natural process of pear ripening. At relatively low concentrations, these volatiles may be beneficial to flavor development or as substrates for biosynthesizing other characteristic aromas.

Preclimacteric pears exposed to $0.25 \% \mathrm{O}_{2}, 20 \% \mathrm{O}_{2}+80 \% \mathrm{CO}_{2}$, or $0.25 \% \mathrm{O}_{2}+80 \% \mathrm{CO}_{2}$ at $20 \mathrm{C}$ for 1 to 3 days accumulated more acetaldehyde, ethanol, and ethyl acetate (Fig. $1 \mathrm{~A}, \mathrm{C}$, and E) than air control fruit. Higher concentrations of these fermentation volatiles were found in postclimacteric fruit (Fig. $1 \mathrm{~B}, \mathrm{D}$, and F). Boersig et al. (1988) found that ripe pears were less tolerant to low $\mathrm{O}_{2}$ since a higher $\mathrm{O}_{2}$ concentration was required to maintain aerobic respiration when the fruit became more mature.

The large increases in concentrations of fermentation volatiles, especially in the postclimacteric pears, by the very low $\mathrm{O}_{2}$ and/or very high $\mathrm{CO}_{2}$ atmospheres may be detrimental to the commodity since high concentrations of these volatiles may cause off-flavors (Ke and Kader, 1990; Ke et al., 1991b).

PDC extractable activity in postclimacteric pears was 2 to 3 times greater than that in preclimacteric fruit (Fig. 2 A and B). For postclimacteric pears, PDC activity was higher in fruit kept in $0.25 \% \mathrm{O}_{2}, 20 \% \mathrm{O}_{2}+80 \% \mathrm{CO}_{2}$, or $0.25 \% \mathrm{O}_{2}+80 \% \mathrm{CO}_{2}$ than in the air control fruit (Fig. 2B); the CA effect on PDC activity was less obvious in preclimacteric pears (Fig. 2A).

After 2 to 3 days, ADH activity was slightly increased by $20 \%$ $\mathrm{O}_{2}+80 \% \mathrm{CO}_{2}$ in preclimacteric and postclimacteric pears (Fig. 2 $\mathrm{C}$ and $\mathrm{D})$. For the preclimacteric pears, much higher ADH activity was induced by $0.25 \% \mathrm{O}_{2}$; however, $0.25 \% \mathrm{O}_{2}+80 \% \mathrm{CO}_{2}$ resulted in lower $\mathrm{ADH}$ activity than $0.25 \% \mathrm{O}_{2}$ alone (Fig. 2C). For postclimacteric pears, ADH activity was similar for the fruit kept in $0.25 \% \mathrm{O}_{2}$ alone or in $0.25 \% \mathrm{O}_{2}+80 \% \mathrm{CO}_{2}$ (Fig. 2D). The postclimacteric pears kept in $20 \% \mathrm{O}_{2}+80 \% \mathrm{CO}_{2}$ had the highest acetaldehyde concentration (Fig. 1B) and a low ethanol concentration (Fig. 1D), which may be related to the low ADH activity in the high- $\mathrm{CO}_{2}$-treated fruit (Fig. 2D) compared to the fruit kept in $0.25 \% \mathrm{O}_{2}$ or $0.25 \% \mathrm{O}_{2}+80 \% \mathrm{CO}_{2}$.

There are three ADH isozymes (ADH1, ADH2, and ADH3) in plants (Hanson et al., 1984). The active ADH isozymes do not exist as a single subunit. Instead, they occur as homogeneous or heterogeneous dimers to have function. Theoretically, three $\mathrm{ADH}$ isozymes may result in six dimers (ADH1-ADH1, ADH1-ADH2, ADH1-ADH3, ADH2-ADH2, ADH2-ADH3, and ADH3ADH3). However, not all six dimers could be found in each plant tissue, due to the limited expression of one or two specific ADH isozymes. Using starch gel electrophoresis, only four ADH dimers could be clearly and consistently identified in preclimacteric pears (Fig. 3). Occasionally, two additional ADH dimers appeared at very low intensities, as has been reported by Nanos et al. (1992). After 1 day, only one ADH dimer stained slightly more intensely in fruit kept in $0.25 \% \mathrm{O}_{2}$ than in air control fruit (Fig. 3A). After 3 days, this $\mathrm{ADH}$ dimer stained much more intensely in fruit kept in either $0.25 \% \mathrm{O}_{2}$ or $0.25 \% \mathrm{O}_{2}+80 \% \mathrm{CO}_{2}$ (Fig. 3B); $20 \% \mathrm{O}_{2}+80 \%$ $\mathrm{CO}_{2}$ slightly increased the intensity of this $\mathrm{ADH}$ dimer. Another $\mathrm{ADH}$ dimer stained slightly more intensely in fruit kept in $0.25 \%$ $\mathrm{O}_{2}$ or $0.25 \% \mathrm{O}_{2}+80 \% \mathrm{CO}_{2}$ (Fig. 3B). Generally, the changes in ADH isozymes (Fig. 3) correlated well with changes in extractable ADH activity (Fig. 2C, Table 1) of the preclimacteric pears.

After transferring the low- $\mathrm{O}_{2}$ - and/or high- $\mathrm{CO}_{2}$-treated preclimacteric pears to air for another 3 days, acetaldehyde and ethyl acetate concentrations slightly increased or did not change, while ethanol content decreased (Table 1). During this period, PDC activity in fruit treated with $0.25 \% \mathrm{O}_{2}$ or $0.25 \% \mathrm{O}_{2}+80 \% \mathrm{CO}_{2}$ slightly decreased, while ADH activity in fruit treated with $0.25 \%$ $\mathrm{O}_{2}+80 \% \mathrm{CO}_{2}$ slightly increased (Table 1 ). The low- $\mathrm{O}_{2}-$ and/or high- $\mathrm{CO}_{2}$-induced $\mathrm{ADH}$ isozymes (Fig. 3C) were similar to those observed at transfer (Fig. 3B).

$P D C$ and $A D H$ regulation. $\mathrm{PDC}$ and $\mathrm{ADH}$ induction is generally regarded as one of the reasons for anaerobic volatile accumulation (Kennedy et al., 1992). In several studies (Gerlach et al., 1982; Good and Crosby, 1989; Kelley, 1989), increased PDC and $\mathrm{ADH}$ activity has been found to be due to increased transcription and translation, resulting in new mRNA synthesis and de novo synthesis of the corresponding enzyme proteins.

Our data (Figs. 1 and 2, Table 1) indicate that, although low $\mathrm{O}_{2}$ and high $\mathrm{CO}_{2}$ generally increased PDC and ADH activities, the changes in the extractable activities of these two fermentation enzymes did not always correlate with the concentrations of their corresponding products. For example, $0.25 \% \mathrm{O}_{2}$ induced much higher $\mathrm{ADH}$ activity than $0.25 \% \mathrm{O}_{2}+80 \% \mathrm{CO}_{2}$ in preclimacteric pears (Fig. 2C), but the combination treatment caused more ethanol to accumulate (Fig. 1C). The changes in ADH isozymes

Table 1. Concentrations of fermentation volatiles and activities of pyruvate decarboxylase (PDC) and alcohol dehydrogenase (ADH) in preclimacteric 'Bartlett' pears kept in air, $0.25 \% \mathrm{O}_{2}, 20 \% \mathrm{O}_{2}+80 \% \mathrm{CO}_{2}$, or $0.25 \% \mathrm{O}_{2}+80 \% \mathrm{CO}_{2}$ for 3 days (day 3 ) followed by storage in air for another 3 days (day 6) at 20C.

\begin{tabular}{|c|c|c|c|c|c|c|c|c|c|c|}
\hline \multirow[b]{3}{*}{ Treatment } & \multicolumn{6}{|c|}{ Volatile concn (mM) } & \multicolumn{4}{|c|}{ Enzyme activity $\left(\mu \mathrm{mol} \cdot \mathrm{min}^{-1} \cdot \mathrm{g}^{-1}\right)$} \\
\hline & \multicolumn{2}{|c|}{ Acetaldehyde } & \multicolumn{2}{|c|}{ Ethanol } & \multicolumn{2}{|c|}{ Ethyl acetate } & \multicolumn{2}{|c|}{ PDC } & \multicolumn{2}{|c|}{$\mathrm{ADH}$} \\
\hline & Day 3 & Day 6 & Day 3 & Day 6 & Day 3 & Day 6 & Day 3 & Day 6 & Day 3 & Day 6 \\
\hline$\overline{\text { Air }}$ & 0.07 & 0.32 & 0.2 & 1.5 & 0.00 & 0.02 & 0.27 & 0.28 & 0.25 & 0.29 \\
\hline $0.25 \% \mathrm{O}_{2}$ & 0.61 & 0.85 & 22.9 & 11.8 & 0.04 & 0.14 & 0.32 & 0.27 & 0.84 & 0.78 \\
\hline $20 \% \mathrm{O}_{2}+80 \% \mathrm{CO}_{2}$ & 0.24 & 0.35 & 8.2 & 3.1 & 0.08 & 0.08 & 0.25 & 0.24 & 0.32 & 0.34 \\
\hline $0.25 \% \mathrm{O}_{2}+80 \% \mathrm{CO}_{2}$ & 0.62 & 0.76 & 37.2 & 23.9 & 0.14 & 0.15 & 0.32 & 0.23 & 0.42 & 0.55 \\
\hline $\operatorname{LSD}(P=0.05)$ & \multicolumn{2}{|c|}{0.13} & \multicolumn{2}{|c|}{4.4} & \multicolumn{2}{|c|}{0.03} & \multicolumn{2}{|c|}{0.04} & \multicolumn{2}{|c|}{0.07} \\
\hline
\end{tabular}




\section{Preclimacteric pear}

\section{Postclimacteric pear}

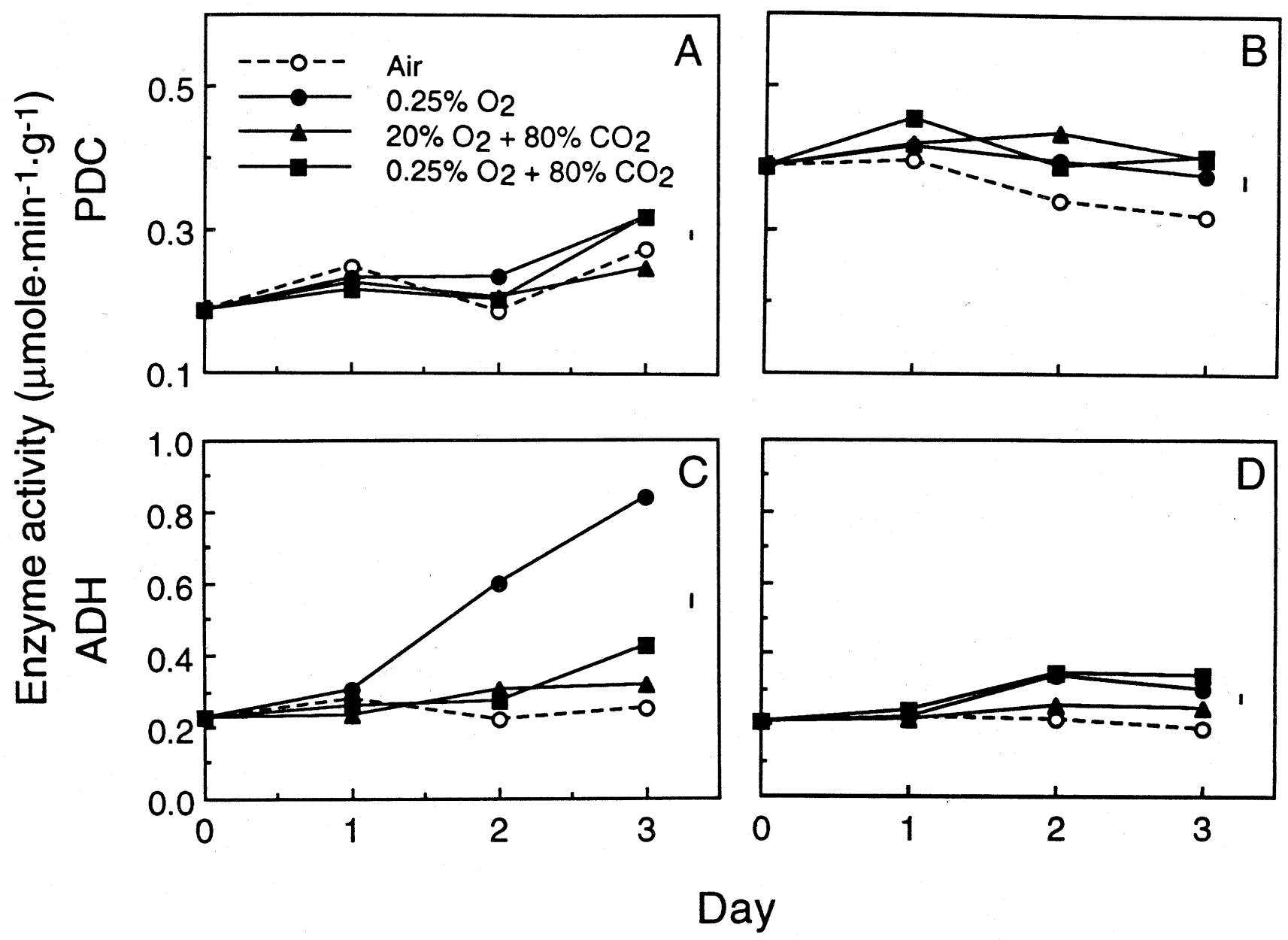

Fig. 2. Changes in pyruvate decarboxylase (PDC) and alcohol dehydrogenase (ADH) activities in preclimacteric and postclimacteric 'Bartlett' pears kept in air, $0.25 \%$ $\mathrm{O}_{2}, 20 \% \mathrm{O}_{2}+80 \% \mathrm{CO}_{2}$, or $0.25 \% \mathrm{O}_{2}+80 \% \mathrm{CO}_{2}$ at $20 \mathrm{C}$ for 1,2 , or 3 days. The vertical bars represent $\mathrm{LSD}$ at $P=0.05$.

(Fig. 3B) also could not explain why $0.25 \% \mathrm{O}_{2}+80 \% \mathrm{CO}_{2}$ induced higher ethanol accumulation than $0.25 \% \mathrm{O}_{2}$ alone. Similarly, although $0.25 \% \mathrm{O}_{2}$ caused more ethanol to accumulate in postclimacteric (Fig. 1D) than that in preclimacteric pears (Fig. 1C), this treatment induced much higher ADH activity in preclimacteric pears (Fig. 2C). On the other hand, postclimacteric pears had higher PDC activity (Fig. 2B) and greater acetaldehyde accumulation (Fig. 1B) compared to preclimacteric fruit. Chang et al. (1983) suggested that PDC was more likely to be a rate-limiting enzyme for ethanolic fermentation than ADH in sweetpotatoes. Roberts et al. (1989) reported that ethanol production rate was correlated with ADH activity when the enzyme level was very low, but, at high enzyme levels, ethanol production was independent of ADH activity. For 'Bartlett' pears, the extractable ADH activity of $0.55 \mathrm{mmol} \cdot \mathrm{min}^{-1} \cdot \mathrm{g}^{-1}$ seemed to be high enough for ethanol accumulation (Fig. $1 \mathrm{C}$ and D, Fig. $2 \mathrm{C}$ and D, Table 1).

It seems that only measuring PDC and $\mathrm{ADH}$ activities does not adequately explain the differences in acetaldehyde, ethanol, and ethyl acetate concentrations in preclimacteric and postclimacteric pears exposed to the three atmospheres. Other metabolic factors may also be involved in regulating ethanolic fermentation.

One of these factors may be the change in cytoplasmic $\mathrm{pH}$. Davies (1980) and Roberts (1989) proposed that, under limited $\mathrm{O}_{2}$ supply, cytoplasmic $\mathrm{pH}$ decreased, which activated PDC and induced ethanolic fermentation. The cytoplasmic $\mathrm{pH}$ of 'Bartlett' pears kept in air was 7.4; exposure to $0.25 \% \mathrm{O}_{2}$ decreased cytoplasmic $\mathrm{pH}$ to 7.0 (Nanos and Kader, 1993) and exposure to elevated $\mathrm{CO}_{2}$ atmospheres caused the cytoplasmic $\mathrm{pH}$ to drop to 6.6 (Chavez, 1991). The optimum $\mathrm{pH}$ for PDC and ADH was 6 (Fig. 4). The decreases in cytoplasmic $\mathrm{pH}$ by low $\mathrm{O}_{2}$ and/or high $\mathrm{CO}_{2}$ would significantly activate PDC and slightly activate ADH.

Another factor could be the changes in substrate concentrations. PDC was reported to be an allosteric enzyme (Hubner et al., 1978). This enzyme had a Km value of $0.84 \mathrm{~mm}$ for pyruvate (Fig. 5). PDC was not active at pyruvate concentrations $<0.1 \mathrm{~mm}$, but it became much more active if the substrate concentration was increased to $0.25 \mathrm{~mm}$ (Fig. 5). Davis et al. (1973) reported that pyruvate concentration in orange was 0.02 to $0.1 \mathrm{~mm}$ and that low $\mathrm{O}_{2}$ and high $\mathrm{CO}_{2}$ atmospheres increased pyruvate concentration. Such an increase in pyruvate concentration by stress atmospheres would, in turn, activate PDC due to a conformation change of the allosteric enzyme through the combination to its substrate.

$\mathrm{ADH}$ had a Km value of $0.86 \mathrm{~mm}$ for acetaldehyde (Fig. 6). For preclimacteric pears, air control fruit had an acetaldehyde concentration of 0.04 to $0.08 \mathrm{~mm}$ (Fig. 1, Table 1), which was much lower than the $\mathrm{Km}$ value. When the pears were ripe, acetaldehyde concentration of the air control fruit reached 0.3 to $0.8 \mathrm{~mm}$. The CA treatments increased acetaldehyde concentration to near or above the $\mathrm{Km}$ value of $\mathrm{ADH}$ in preclimacteric and postclimacteric pears. The increase in acetaldehyde concentration could have partly 


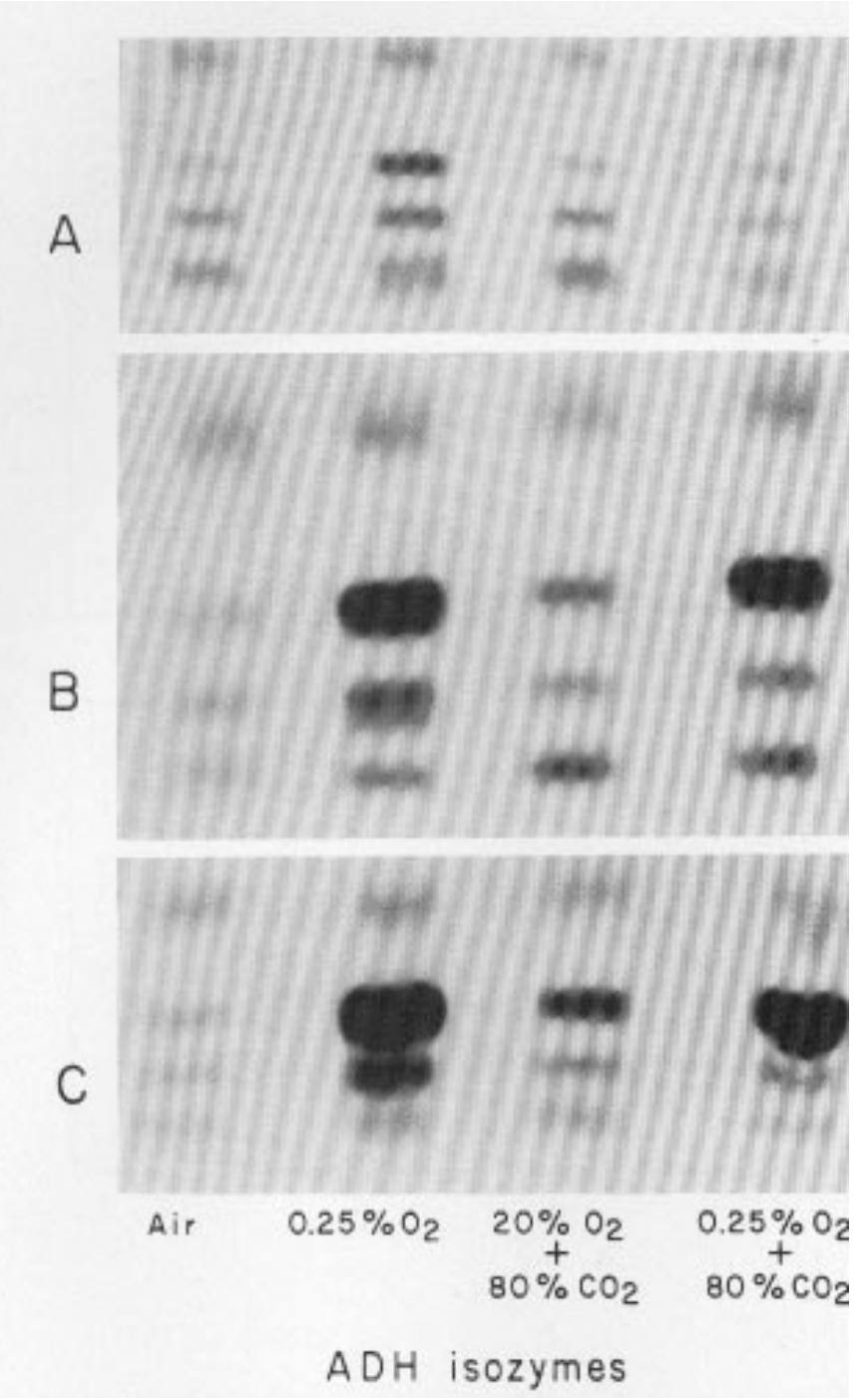

Fig. 3. Changes in alcohol dehydrogenase (ADH) isozymes in preclimacteric 'Bartlett' pears kept in air, $0.25 \% \mathrm{O}_{2}, 20 \% \mathrm{O}_{2}+80 \% \mathrm{CO}_{2}$, or $0.25 \% \mathrm{O}_{2}+80 \% \mathrm{CO}$ for 1 (A) or 3 days (B) followed by storage in air for another 3 days $(\mathbf{C})$ at $20 \mathrm{C}$. Top is the anode and bottom is the cathode in each section.

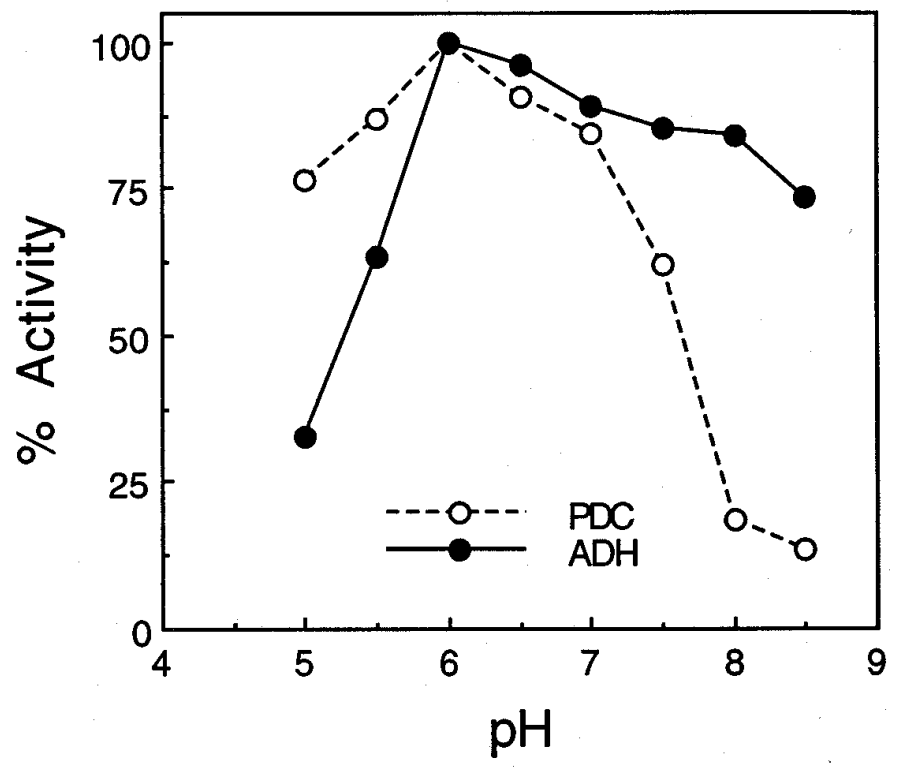

Fig. 4. Pyruvate decarboxylase (PDC) and alcohol dehydrogenase (ADH) activities in 'Bartlett' pears as influenced by $\mathrm{pH}$. contributed to ethanol accumulation in the fruit.

The Km value of ADH for NADH (Fig. 6) was much lower than that for acetaldehyde. If no NAD was added, $\mathrm{ADH}$ had a $\mathrm{Km}$ value of $0.023 \mathrm{~mm}$ for NADH; if $0.08 \mathrm{~mm}$ NAD was added, the Km value of $\mathrm{ADH}$ for NADH increased to $0.057 \mathrm{~mm}$. Since oxidative phosphorylation of 'Bartlett' pears was strongly inhibited by low $\mathrm{O}_{2}$ (Nanos and Kader, 1993) or high $\mathrm{CO}_{2}$ (Chavez, 1991), as indicated by reduced ATP levels, electron transport through the cytochrome pathway could have been greatly reduced. This could increase NADH concentration and decrease NAD concentration, which in turn reduces the $\mathrm{Km}$ value of ADH for NADH and activates the enzyme. The induction of ethanol biosynthesis will use NADH and prevent its further accumulation in the tissue.

\section{Conclusion}

Low $\mathrm{O}_{2}$ and/or high $\mathrm{CO}_{2}$ concentrations may induce ethanolic fermentation (Fig. 7) by one or more of the following means: 1) increased amounts of PDC and ADH due to de novo biosynthesis;
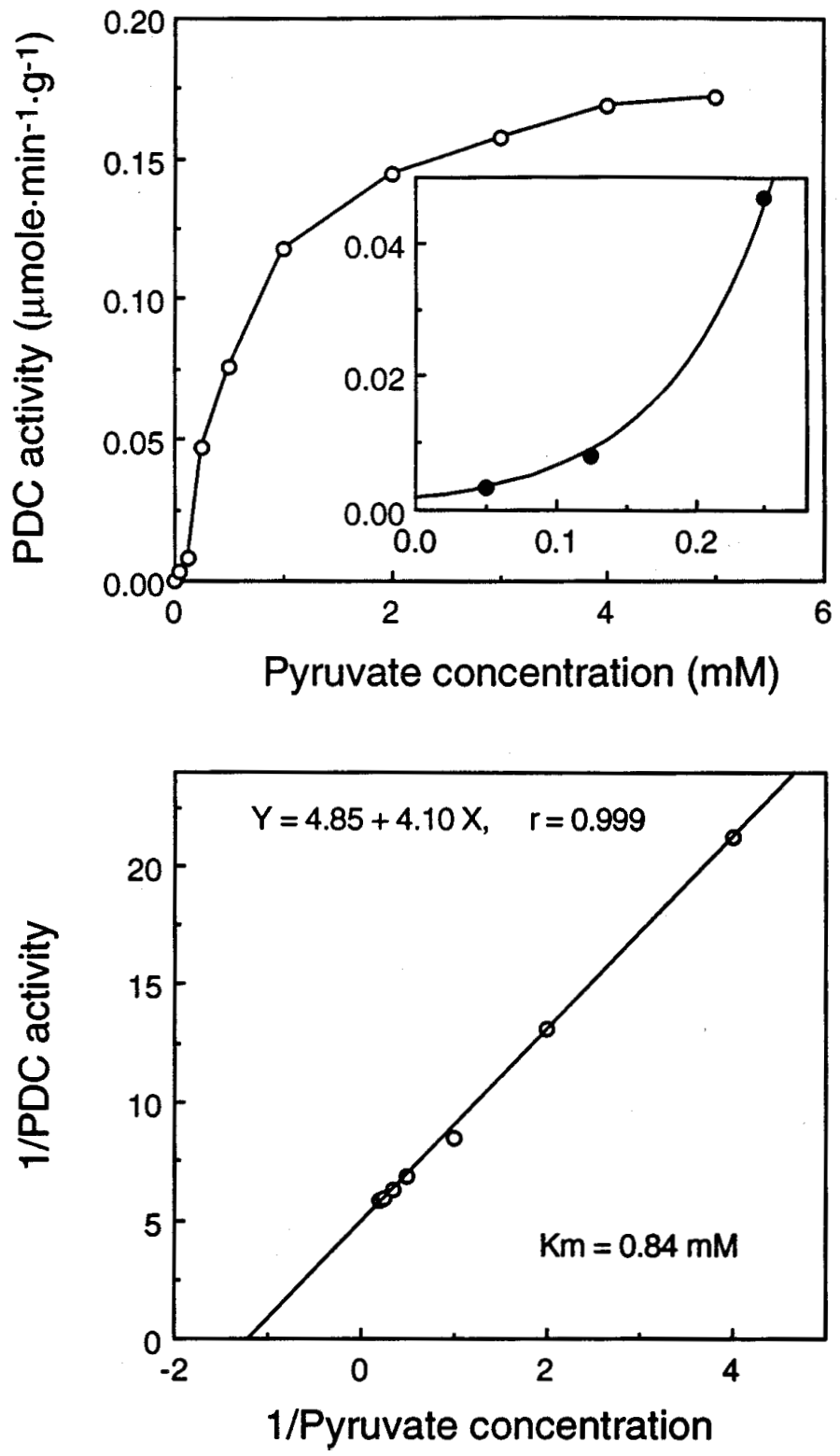

Fig. 5. Pyruvate decarboxylase (PDC) activity in 'Bartlett' pears as influenced by pyruvate concentration. 

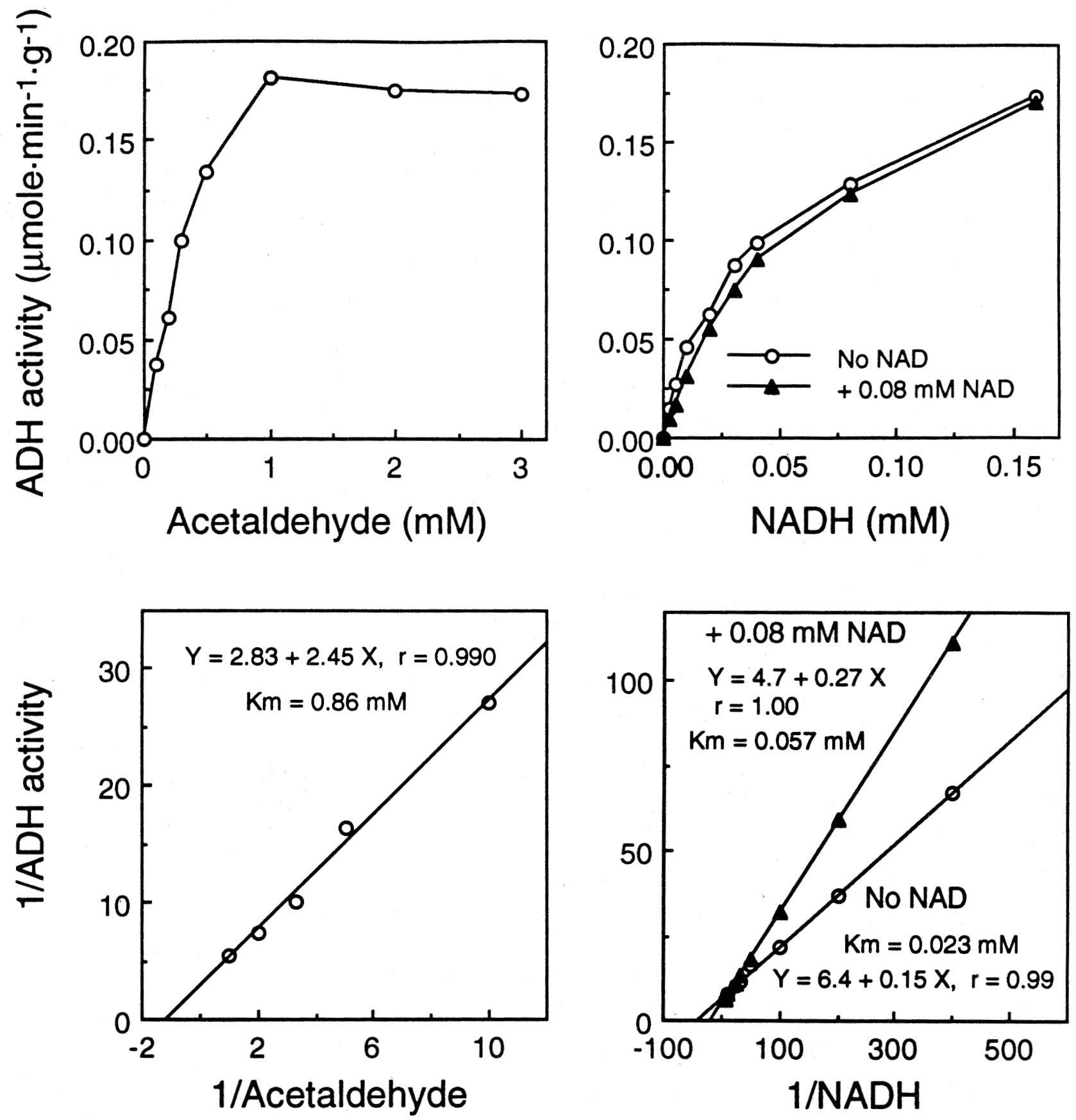

Fig. 6. Alcohol dehydrogenase (ADH) activity in 'Bartlett' pears as influenced by acetaldehyde and NADH concentrations with or without 0.08 mm NAD.

2) $\mathrm{PDC}$ and $\mathrm{ADH}$ activation by a decrease in cytoplasmic $\mathrm{pH}$; and 3) PDC and ADH activation and more rapid fermentation due to increased pyruvate, acetaldehyde, and NADH concentrations and decreased NAD level. ADH is induced to a greater extent by low $\mathrm{O}_{2}$ than high $\mathrm{CO}_{2}$ atmospheres. On the other hand, high $\mathrm{CO}_{2}$ decreases cytoplasmic $\mathrm{pH}$ to a greater degree, which has a stronger effect on PDC activation. The induction of ethanolic fermentation will use NADH and allow glycolysis to go on. A small amount of ATP can be produced through substrate phosphorylation to permit the plant tissue to survive temporarily. However, acetaldehyde, ethanol, and ethyl acetate accumulation may cause detrimental effects if their concentrations are beyond the tolerance limits of plant tissues. Postclimacteric pears were more sensitive to low $\mathrm{O}_{2}$ and/or high $\mathrm{CO}_{2}$, as indicated by greater acetaldehyde, ethanol, and ethyl acetate accumulation compared to preclimacteric fruit.

\section{Literature Cited}

Arulsekar, S. and D.E. Parfitt. 1986. Isozyme analysis procedures for stone fruits, almond, grape, walnut, pistachio and fig. HortScience 21:928-933.

Boersig, M.R., A.A. Kader, and R.J. Romani. 1988. The aerobic-anaerobic respiratory transition in pear fruit and cultured pear fruit cells. J. Amer. Soc. Hort. Sci. 113:869-873.

Chang, L.A., L.K. Hammett, and D.M. Pharr. 1982. Ethanol, alcohol dehydrogenase and pyruvate decarboxylase in storage roots of four sweet potato cultivars during simulated flood damage and storage. J. Amer. Soc. Hort. Sci. 107:674677.

Chang, L.A., L.K. Hammett, and D.M. Pharr. 1983. Carbon dioxide effects on ethanol production, pyruvate decarboxylase, and alcohol dehydrogenase activities in anaerobic sweet potato roots. Plant Physiol. 71:59-62.

Chavez Franco, S.H. 1991. Effects of $\mathrm{CO}_{2}$ levels on ethylene biosynthesis and action in pear fruit (pyrus communis L.). PhD diss. Univ of California, Davis. Davies, D.D. 1980. Anaerobic metabolism and the production of organic acids, p. 


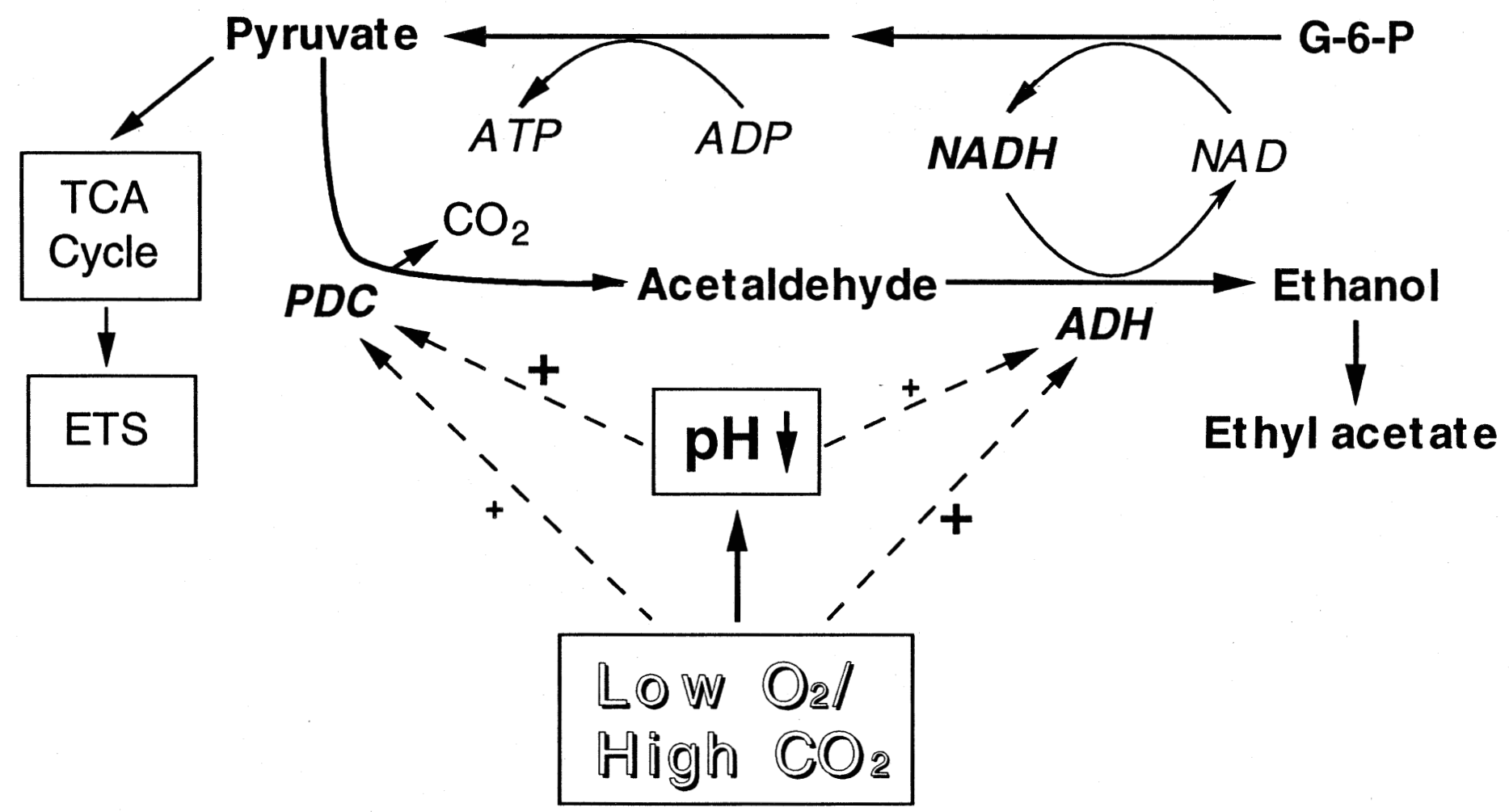

Fig. 7. Ethanolic fermentation pathway in 'Bartlett' pears as proposed to be regulated by low $\mathrm{O}_{2}$ and/or high $\mathrm{CO}_{2}$ atmospheres. G-6-P = glucose-6-phosphate, $\mathrm{PDC}=$

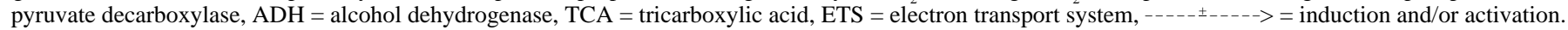

581-611. In: P.K. Stumpf and E.E. Conn (eds.). The biochemistry of plants: A comprehensive treatise. vol. 2. Academic Press, New York.

Davis, P.L., B. Roe, and J.H. Bruemmer. 1973. Biochemical changes in citrus fruits during controlled-atmosphere storage. J. Food Sci. 38:225-229.

Gerlach, W.L., A.J. Pryor, E.S. Dennis, R.J. Ferl, M.M. Sachs, and W.J. Peacock. 1982. cDNA cloning and induction of alcohol dehydrogenase gene (Adh1) of maize. Proc. Natl. Acad. Sci. USA 79:2981-2985.

Good, A.G. and W.L. Crosby. 1989. Induction of alcohol dehydrogenase and lactate dehydrogenase in hypoxically induced barley. Plant Physiol. 90:860-866.

Hanson, A.D., J.V. Jacobsen, and J.A. Zwar. 1984. Regulated expression of three alcohol dehydrogenase genes in barley aleurone layers. Plant Physiol. 75:573581 .

Hubner, G., R. Weidhase, and A. Schellenberger. 1978. The mechanism of substrate activation of pyruvate decarboxylase: A first approach. Eur. J. Biochem. 92:175-181.

John, C.D. and H. Greenway. 1976. Alcoholic fermentation and activity of some enzymes in rice roots under anaerobiosis. Austral. J. Plant Physiol. 3:325-336.

Kanellis, A.K., T. Solomos, and K.A. Roubelakis-Angelakis. 1991. Suppression of cellulase and polygalacturonase and induction of alcohol dehydrogenase isozymes in avocado fruit mesocarp subjected to low oxygen stress. Plant Physiol. 96:269274.

Ke, D., L. Goldstein, M. O'Mahony, and A. Kader. 1991a. Effects of short term exposures to low $\mathrm{O}_{2}$ or high $\mathrm{CO}_{2}$ atmospheres on quality attributes of strawberries. J. Food Sci. 56:50-54.

Ke, D. and A.A. Kader. 1990. Tolerance of 'Valencia' oranges to controlled atmospheres as determined by physiological responses and quality attributes. J. Amer. Soc. Hort. Sci. 115:779-783.

Ke, D. and A.A. Kader. 1992. External and internal factors influence fruit tolerance to low-oxygen atmospheres. J. Amer. Soc. Hort. Sci. 117:913-918.

Ke, D., L. Rodriguez, and A.A. Kader. 1991b. Physiology and prediction of fruit tolerance to low-oxygen atmospheres. J. Amer. Soc. Hort. Sci. 116:253-260.

Ke, D., H. van Gorsel, and A.A. Kader. 1990. Physiological and quality responses of Bartlett' pears to reduced $\mathrm{O}_{2}$ and enhanced $\mathrm{CO}_{2}$ levels and storage temperature. J. Amer. Soc. Hort. Sci. 115:435-439.

Kelley, P.M. 1989. Maize pyruvate decarboxylase mRNA is induced anaerobically. Plant Mol. Biol. 13:213-222.

Kennedy, R.A., M.E. Rumpho, and T.C. Fox. 1992. Anaerobic metabolism in plants. Plant Physiol. 100:1-6.

Knee, M. 1991. Fruit metabolism and practical problems of fruit storage under hypoxia and anoxia, p. 229-243. In: M.B. Jackson, D.D. Davies, and H. Lambers (eds.). Plant life under oxygen deprivation. SPB Academic Publishing, The Hague, The Netherlands.

Leshuk, J.A. and M.E. Saltveit, Jr. 1991. Effects of rapid changes in oxygen concentration on respiration of carrot roots. Physiol. Plant. 82:559-568.

Longhurst, T.J., H.F. Tung, and C.J. Brady. 1990. Developmental regulation of the expression of alcohol dehydrogenase in ripening tomato fruits. J. Food Biochem. 14:421-433.

Nanos, G.D. and A.A. Kader. 1993. Low $\mathrm{O}_{2}$-induced changes in pH and energy charge in pear fruit tissue. Postharvest Biol. Technol. 3: 285-291.

Nanos, G.D., R.J. Romani, and A.A. Kader. 1992. Metabolic and other responses of 'Bartlett' pear fruit and suspension-cultured 'Passe Crassane' pear fruit cells held in $0.25 \% \mathrm{O}_{2}$. J. Amer. Soc. Hort. Sci. 117:934-940.

Nichols, W.C. and M.E. Patterson. 1987. Ethanol accumulation and poststorage quality of 'Delicious' apples during short-term, low- $\mathrm{O}_{2}, \mathrm{CA}$ storage. HortScience 22:89-92.

Roberts, J.K.M. 1989. Cytoplasmic acidosis and flooding tolerance in crop plants, p. 392-397. In: D.D. Hook (ed.). The ecology and management of wetlands. vol. 1. Croom-Helm Press, London.

Roberts, J.K.M., K. Chang, C. Webster, J. Callis, and V. Walbot. 1989. Dependence of ethanolic fermentation, cytoplasmic $\mathrm{pH}$ regulation, and viability on the activity of alcohol dehydrogenase in hypoxic maize root tips. Plant Physiol. 89:12751278.

Saltveit, Jr., M.E. and W.E. Ballinger. 1983a. Effects of anaerobic nitrogen and carbon dioxide atmospheres on ethanol production and postharvest quality of blueberries. J. Amer. Soc. Hort. Sci. 108:459-462.

Saltveit, Jr., M.E. and W.E. Ballinger. 1983b. Effects of anaerobic nitrogen and carbon dioxide atmospheres on ethanol production and postharvest quality of 'Carlos' grapes. J. Amer. Soc. Hort. Sci. 108:462-465.

Smilanick, J.L. and D.C. Fouse. 1989. Quality of nectarines stored in insecticidal low- $\mathrm{O}_{2}$ atmospheres at 5 and 15C. J. Amer. Soc. Hort. Sci. 114:431-436.

Thomas, M. 1929. The production of ethyl alcohol and acetaldehyde by apples in relation to the injuries occurring in storage. Part I. Injuries to apples occurring in the absence of oxygen and in certain mixtures of carbon dioxide and oxygen. Ann. Applied Biol. 16: 444-458. 